\title{
鉄筋コンクリート無開口及び有開口単独壁の 剪断抵抗に関寸る研究
}

\section{I 本研究の意義と既往の実験的諸研究の概要 \\ $\$ 1 \cdot 1$ 本研究の内容とその意義 \\ 壁は水平力に対して}

1) 剪断抵抗、2) 曲げ抵抗、3）回転抵抗 をなす。れを具体的に述べると、壁の岡性 $D$ は 無開口壁 : $1 / D=1 / D_{S}+1 / D_{B}+1 / D_{R} \cdots \cdots \cdots(1 \cdot 1)$ 有開口壁 : $1 / D=1 / D_{F}+1 / D_{B}+1 / D_{R} \cdots \cdots \cdots(1 \cdot 2)$ のよ5飞、剪断岡性 $D_{S}$, ラーメン的岡性 $D_{F}$, 曲げ 岡胜 $D_{B}$, 回転岡胜 $D_{R}$ の要素儿分析される ${ }^{28)}$ (詳細 忹 $\$ 1.3$ 参照)。 $D_{R}$ 恃地盤係数が与えられ入ば岡体 の回転抵抗として簡単に解析できるものであり、 $D_{B}$ は線材の主要抵抗要素としてすでに多くの研究がなさ れている。 $D_{S}, D_{F}$ は版の主要抵抗要素と考光られる ๖のであつて、既往の実験的諸研究もこの追究に主眼 が置かれたように推察される。併し $D_{S}, D_{F}$ だけを 単独に取出して実験的検討を加えることは難題であつ て、既往の研究もこれを解決したものがない（\$1.2 参照)。著者は薄肉门壔試験体の捱り試験法を採用し、 薄肉円壔（外径 $14.9 \mathrm{~cm}$, 内径 $13.4 \mathrm{~cm}$ ) 飞置換えた 壁に純䊅剪断を与えてこの問題を解決した。これに類 する試験法を採用したるのとしては、古くは E. Mör$\mathrm{sch}$ の中空円壔柱 (外径 $26 \mathrm{~cm}$, 内径 $16.2 \mathrm{~cm}$ 及び 15 $\mathrm{cm}$ ) の捱り試験 ${ }^{24}$ 、Bach そ Graf の中空円橲柱（外 径 $40 \mathrm{~cm}$, 内径 $25 \mathrm{~cm}$ ) の捩り試験 ${ }^{25}$ があり、又最近 では B. Bresler と E. Wollak そよるコンクリート の加圧剪断試験 (外径 9 in., 内径 6 in.) ${ }^{26)}$ があるが、 いずれる厚肉のるのである。

著者は前記試験法により、コンクリートの替りにそ ルタルを使用して

鉄筋コンクリート無開口単独壁の剪断抵抗 (既報 $\left.{ }^{9}\right)$ を検討するとともに、円壔軸に対称な開口部 2 個を円 壔面に設けることにより近似的に

無限連続張間有開口壁単独の剪断抵抗（本論揭載） をも検討した。有開口壁に関しては、その開口が充分

$\begin{array}{lllll}\text { 正会員 } & \text { 坪 } & \text { 井 } & \text { 善 } & \text { 勝* } \\ \text { 正会員 } & \text { 富 } & \text { 井 } & \text { 政 } & \text { 英** }\end{array}$

大きい場合については岡域を考慮したラーメン解法に よつて実用的に追究できることが指適されたが19)、開 口が小さい場合についてはほとんどそのすべてを実験 的研究に負わなけれげならない現状である は両者の限界と考劣られる空型開口 $(l / 3 \times h / 3)$ 及び 屝型開口 $(l / 3 \times 2 h / 3)$ を有する壁に対し、その辺長比 $\lambda=l / h$ を種々変化させた場合につき、薄肉円壔の断面 を一定とし、その高さを種々変化させた試験体によつ て検討を加えた。

又既往のすべての実験的研究がシリンダー型試験体 又はヨーカン型試験体によつて間接にその材料学的性 状の検討を行つていたのに反し、本論では薄肉円壔試 験体の引張及び圧縮の各試験を行い、直接各試験結果 の比較検討を試みたことも一つの特色と云える（\$3. 1 参照)。

\section{$\S 1.2$ 壁の剪断抵抗に関する実験法}

こ」には既往の実験法を大別し、本論が属する「鉄 筫コンクリートによる直接実験法」を分類してその特 徵を示す。

I 動的試験法

II 静的試験法

1. 実大建物の加力試験

2. 模型試験

a. 鉄筋コンクリート（モルタルを含も）に よる直接実験法 ${ }^{12}$ (2).

b. 弾性体による間接実験法 ${ }^{13 \sim 22)}$

$$
\begin{aligned}
& \text { i ゴム試験体を使用したもの }{ }^{14) \sim 17)} \\
& \text { ii 光弾性実験法 }{ }^{18)} \text { 22) } \\
& \text { iii その他 }{ }^{13)}
\end{aligned}
$$

鉄筋コンクリートによる直接実験法の内容

\section{1. 曲(゙゙試験法 ${ }^{1) 〜 6)}$}

a 単純梁型試験体の曲げ試験法 $\left.\left.{ }^{1)}, 21,4\right), 51,6\right)$
b 片持梁型試験体の曲げ試験法
${ }^{3}$

* 東京大学教授、工学博士、研究指導者

** 東京都立大学講師、東京大学生産技術研究所研究員、研究担当者 


\section{して適当}

2. 在縮試験法 ${ }^{7}$

架構付き壁の対角線を圧綰する方法で周辺架構の 岡性が充分大きい架構付き壁に対しては純精剪断 飞近い状態が得られ、簡単で手際の良い実験法

3. 挨り試験法 ${ }^{8)}$,9

a. 同心有孔円版試験体の掺り試験法 ${ }^{8)}$

著者が周辺架構の束縛作用を供う架構付き壁の剪 断抵抭を検討する際に採用したるので、純料剪断 が得られる。

b. 薄肉円譸試験体の掺り試験法 ${ }^{9}$

著者が単独壁の剪断抵抗を検討するのに採用した もので、純粋剪断が得られる。すなわち重裂発生 前は等方性で剪断力によつては面積変化を起さな 、訳だから問題なく純粋剪断が得られ、又剪断重 裂発生後の $45^{\circ}$ 張直交異方性状態では圧力場を形 成し、剪断力を受けると面積が拡がることになる $か^{30)}$ 、これ次て付加される応力は薄肉円壔画 端つば部の束縛端近傍にだけ生ずるので（第 1.1 図参照)，円壔の高さを充分大きくとれば、純粋 剪断が得られると見做して差支えない。

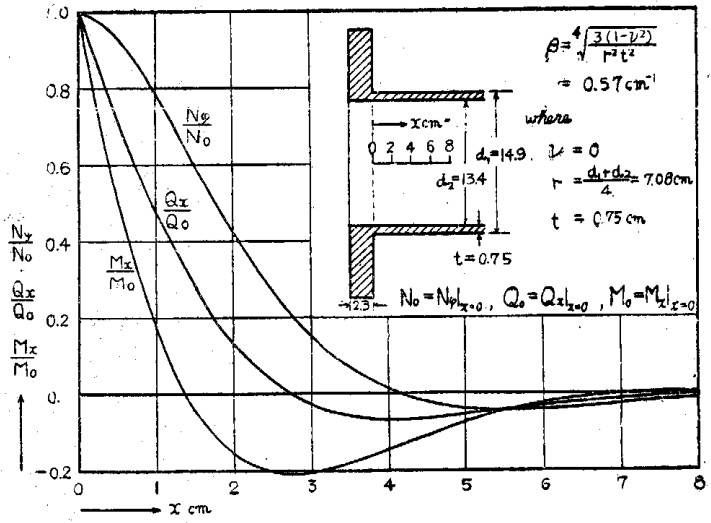

第1.1图，剪断龜裂発生後飞於ける薄肉円境 雨端飞生ずる束縛応力

4. 斜倒十字型試験体の加力試験法 ${ }^{10), 22}$ 開口隅角部を検討するのに適したもの。

5. 模型家屋の水平加力試験法 ${ }^{11), 12)}$

\section{$\S 1.3$ 有開口壁に関する既往の実験的諸研究の概要}

有開口壁に関する既往の実験的諸研究の共通点纹

1.ほとえどが弾性体を使用して間接に実験を行つて いる。

2. 開口の位置及びその大きさに主眼が置かれてい る。

3. 特殊なるのを除いては曲げ試験法を採用した単張
間の実験である。 である。以下速層条件、連張間条件、壁形状の種類に よつてこれらを分類し、寒験結果の検討に際し比輘引 用を行つた諸家の横力分布係数関する算定式を次に 揭げる共通記号によつて示す。

$\eta$ ：無開口壁に対する有開口壁の横力分布係数

$D ：$ 壁剛性、 $D=Q / \delta$

但し、無開口壁 : $\delta=\delta_{S}+\delta_{B}+\delta_{R}$,

有開口壁 : $\delta=\delta_{F}+\delta_{B}+\delta_{R}$

$\delta_{S}$ : 㮍断変形、 $\delta_{F}$ : 有開口壁のラーメン的変形

$\delta_{B}:$ 曲げ変形、 $\delta_{R}:$ 回転変形

$D_{S}:$ 剪断岡性、 $D_{S}=Q / \delta_{S}$

$D_{F}$ : 有開口壁のラーメン的岡性、 $D_{F}=Q / \delta_{F}$

$D_{B}:$ 曲げ岡性、 $D_{B}=Q / \delta_{B}$

$D_{R}:$ 回転洞性、 $D_{R}=Q / \delta_{R}$

$\xi$ : 等価開口周比 $\xi=\frac{\text { 開ロと等面積にして壁と相似な矩形の周長 }}{\text { 壁の周長 }}$

$=\sqrt{\frac{A_{0}}{A_{W}}}=\sqrt{a}$

$a:$ 開口率、 $a=A_{0} / A_{W}=\xi^{2}$

$A_{W}$ : 壁の全面積、 $A_{W}=l \times h$

$A_{0}$ : 開口の面積、 $A_{0}=l^{\prime} \times h^{\prime} \quad l$ : 壁の長さ

$s_{W}$ ：壁の外周長、 $s_{W}=2(l+h) \quad h$ : 壁の高さ

$s_{0}$ : 開口の周長、 $s_{0}=2\left(l^{\prime}+h^{\prime}\right) \quad l^{\prime}$ : 開口の長さ

$n: n=\left(l-l^{\prime}\right) / 2 l$

$h^{\prime}$ : 開口の高さ

$\lambda$ : 辺長比、 $\lambda=l / h$

$r \quad:$ 単独架構の 横力負担理論値

1. 単層単張間壁の実験

a. 坂博士の正方形及び矩形架構付き壁に関するゴ 么実験 ${ }^{14), 15)}$

$\eta=1-(1-r)\left(\frac{1}{2} \xi+2 \xi^{2}-\frac{3}{2} \xi^{3}\right) .$.

b. 谷口博士の正方形架構付き壁に関するゴム実 験 $^{16)}$

谷口博士の旧算定式 ${ }^{27)}$ :

$$
\eta=\frac{2 n^{3}\left(1+3.5 \lambda^{2}\right)}{1+3.5 n^{2} \lambda^{2}}
$$

谷口博士の新図表值 ${ }^{16)}$ : 上記算定式が開口の高さ $h^{\prime}$ に無関係に与えられる不合理な点を是正する ため、新たにクを開口率 $a$ の函数で表現したる 
のである。このため $\eta-a$ 関係を追 究するのに表題のゴム実験を行うと そるに、既往の鉄算コンタリート壁 ブロック壁、煉瓦壁などの塑性及び 脆性壁の実験結果（但し $\lambda=1$ なる もの）在合世吟味され、 $\eta-a$ 曲線を 図上江設定し、これてもとずいて種 々の算定図表を与えられた。

c. 二見博士、藤本氏の正方形単独壁 に関する光弹性実験 ${ }^{18)}$

2. 多譄単張間壁の奏験

a. 二見博士、藤本氏の正方形単独壁 に関する光弾性実験 ${ }^{19)}$

b. 武藤博士、大沢氏の正方形及び矩 形架構付き壁汇関するゴム実験 ${ }^{17)}$ 壁剛性 $D$ を(1・1) 式及び (1・2) 式のよ5飞分析され、 $D_{S}$ と $D_{F}$ の 此を求める次のような実験式を提案 された

$$
\eta=\frac{D_{F}}{D_{S}}=\frac{\delta_{S}}{\delta_{F}}=1-1.25 \xi
$$

（適用範井 $\xi<0.4 ）$

3. その他の特殊な実験

a. 棚橋博士の正方形壁に関する鍓板の㧥及吴験 ${ }^{13)}$ 版の 2 次元応力と攃みに関する弾性論の相似性

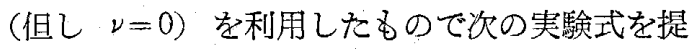
案さ机た。

$$
\eta=1-\frac{s_{W}}{s_{0}}
$$

b. 松井氏の正方形架構付き壁海関する光弾性実 験 $^{21)}$

c. 開口隅角部に関する鉄筋コンクリート ${ }^{10)}$ 及び光 弾性実験 ${ }^{22}$

$$
\text { II 実 験 方 法 }
$$

\section{$\$ 2 \cdot 1$ 試験体の形状及び符号}

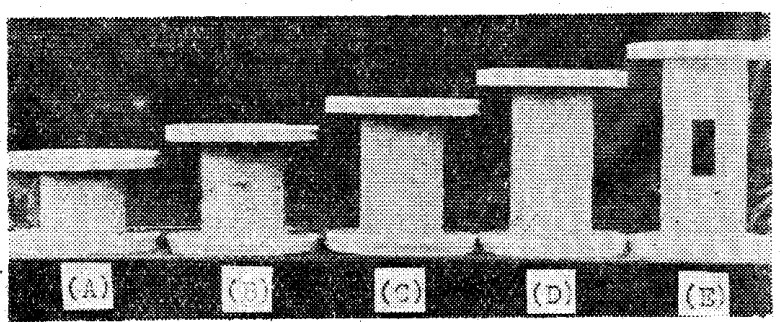

第 2 -1 図円壔の高さ別による試験体符号
第 2.1 表 試験体の形状及び符号

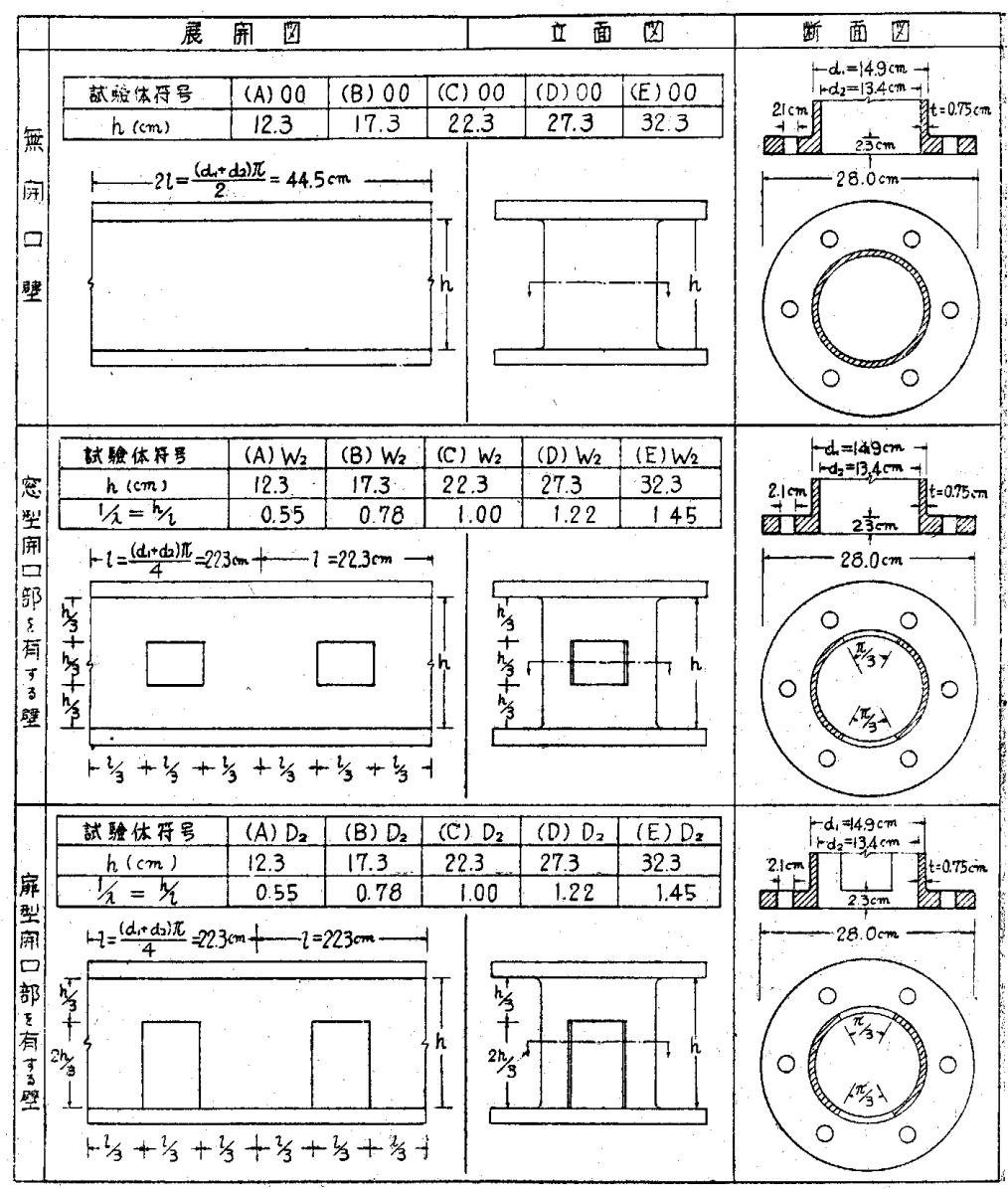

\begin{tabular}{|c|c|}
\hline $\begin{array}{l}\text { 調 合 (重量比) } \\
\text { 水 ‘メント比 }\end{array}$ & $\begin{array}{c}\text { セメント: 砂 }=1: 3 \\
80 \%\end{array}$ \\
\hline $\begin{array}{l}\text { セメントの品質 } \\
\text { 砂 }\end{array}$ & $\begin{array}{c}\text { 冷ルトランドセメント } \\
\text { 旧標準砂 (朝鮮九味浦産理砂) }\end{array}$ \\
\hline $\begin{array}{l}\text { 試験体の製作法 } \\
\text { 開口部の製作法 }\end{array}$ & $\begin{array}{c}\text { 第 } 2.2 \text { 図 参照 } \\
\text { 試験直前無開口詓験体に加エして } \\
\text { 設けた }\end{array}$ \\
\hline 脱型及び養生法 & $\begin{array}{l}3 \text { 日目脱型後 } 6 \text { 週間水中、以後室 } \\
\text { 内放置 }\end{array}$ \\
\hline 期 間 & 昭 $24.7 .21 \sim$ 昭 24.8 .12 \\
\hline 試 験 期，間 & 昭24.9.8 昭 24.10 .4 (材令約 7 週) \\
\hline 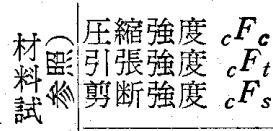 & $\begin{array}{r}134.6 \mathrm{~kg} / \mathrm{cm}^{2} \\
9.3 \mathrm{~kg} / \mathrm{cm}^{2} \\
11.2 \mathrm{~kg} / \mathrm{cm}^{2}\end{array}$ \\
\hline 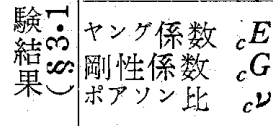 & $c^{\nu=} \begin{array}{r}1.5 \times 10^{5} \mathrm{~kg} / \mathrm{cm}^{2} \\
0.67 \times 10^{5} \mathrm{~kg} / \mathrm{cm}^{2} \\
\left({ }_{c} E / 2_{c} G\right)-1=0.11\end{array}$ \\
\hline
\end{tabular}

\section{$\$ 2 \cdot 2$ 試験体の性状}

第 $2 \cdot 2$ 表 試験体の性状一覧表 


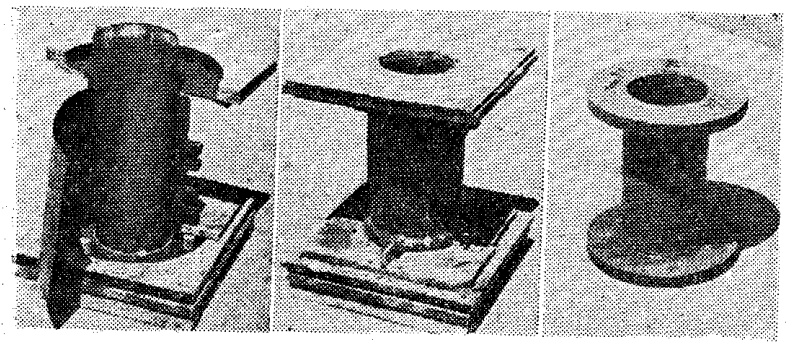

第 $2 \cdot 2$ 図試験体の製作工程（左：型染の組 立，中：モルタル充填完了，右： 脱型を終つた試験体)

\section{$\S 2.3$ 荷重装置及び荷重方法 (既報 ${ }^{9}{ }^{\text {参照) }}$}

各荷重階 $m$ に於ける壁にあたる薄肉円壔部の最大剪 䉼応力度 $\tau_{m}$ は次式で表わされる関係汇ある。

$$
\tau_{m}=1.0 \mathrm{~m} \mathrm{~kg} / \mathrm{cm}^{2}
$$

その他は既報早に準ずる。

$$
\begin{aligned}
& \$ 2.4 \text { 測定装置及び測定方法 (既報 }{ }^{9} \text { 参照) } \\
& \text { 測定間隔 } \quad \Delta \tau=0.5 \mathrm{~kg} / \mathrm{cm}^{2} \\
& \text { その他は既報 }{ }^{9)} \text { そ準ずる。 }
\end{aligned}
$$

\section{III 実験結果とその検討}

\section{§3.1 実験結果の総覧}

応力度歪度曲線と弾性係数の判定について

無開口壁の場合 引張、剪断とも破壊まで注とんど直 線で、 ${ }_{c} E_{t},{ }_{c} G$ を容易に判定できる。圧縮も引張及

第3·1表 無開口壁の引張及び圧縮試験結果一覧表

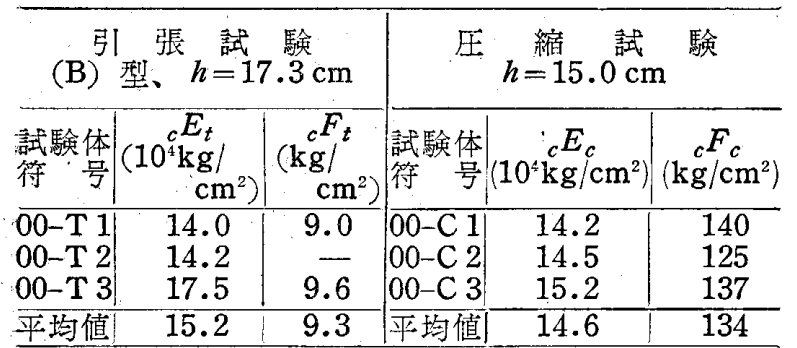

註 i ) ヨーカン試験結果, 曲於破壊係数 ${ }_{c} F_{b}=28.9 \mathrm{~kg} / \mathrm{cm}^{2}$ ${ }_{c} E_{c}=15 \times 10^{4} \mathrm{~kg} / \mathrm{cm}^{2},{ }_{c} F_{c}=111 \mathrm{~kg} / \mathrm{cm}^{2}$

ii ) (00-T 1, 00-C 1) 及び $(00-\mathrm{S} 6,00-\mathrm{T} 2$, 00-C 2) は同じ試験体であるから、各試 験結果から直接諸性状が比較検封できる。
び剪断の各強度以下の低応力では直線と見做され、こ れから ${ }_{c} E_{c}$ を判定した。これによると

$$
{ }_{c} E_{t} \doteqdot{ }_{c} E_{c}
$$

そ考光られる(第 $3 \cdot 1$ 表参照)。

${ }_{c} E$ 及び ${ }_{c} G$ の值からポアソン比 $c^{\nu}$ 女算定すると 0 ・11 となり（第 2.2 表参照）、既報 ${ }^{9)}$ の有筋試験体の 結果と考え合せると、一般には

$$
c^{\nu}=0.1 \sim 0.2
$$

と考光て差支觉なから。

以上の結果から、重裂発生前を対象とした壁の剪断 抵抗の解析にあたつては、等方性弾性理論によつてか なり有効な結果が得られるものと推察される。 有開口壁の場合 偶角部に引裂重裂を発生する直前か ら急飞横這いとなる。 ${ }_{W} G_{F}$ は剪断強度 ${ }_{W} F_{s}$ の 8 割 以下のほとんど直線と見做して差支えない部分より判 定した。

第3·2表 無開口壁の剪断試験結果一覽表

\begin{tabular}{l|c|c|c}
\hline 詿験体符号 & $\begin{array}{c}{ }_{c} G \\
\left(10^{4} \mathrm{~kg} / \mathrm{cm}^{2}\right)\end{array}$ & $\begin{array}{c}c^{F} \\
\left(\mathrm{~kg} / \mathrm{cm}^{2}\right)\end{array}$ & $\begin{array}{l}\text { 同一試験体を他 } \\
\text { 陚験供した } \\
\text { 場合の符号 }\end{array}$ \\
\hline (A) 00-S 1 & 6.9 & - & (A) $W_{2}-\mathrm{S} \mathrm{I}$
\end{tabular}
(A) $00-\mathrm{S} 1$
(A) $00-\mathrm{S} 3$
(A) $00-\mathrm{S} 4$
(B) $00-\mathrm{S} 5$
(B) $00-S 6$
(B) $00-\mathrm{S} 7$
(C) $00-\mathrm{S} 8$
(C) $00-\mathrm{S} 9$
(C) $00-\mathrm{S} 10$
(C) $00-\mathrm{S} 11$
(D) $00-\mathrm{S} 12$
(D) $00-\mathrm{S} 13$

平均值

\begin{tabular}{l|c|}
7.1 & $\overline{9.0^{*}}$ \\
\hline 6.8 & $\overline{11.4}$ \\
6.4 & - \\
6.4 & $\overline{-}$ \\
7.1 & \\
7.0 & $-10.9(11.0)$ \\
6.5 & - \\
6.9 & - \\
7.1 & - \\
6.5 & - \\
6.3 & -
\end{tabular}

(A) $D_{2}-\mathrm{S} 1$

(A) $D_{2}-\mathrm{S} 3$

$00-T 2,00-C 2$

(C) $W_{2}-\mathrm{S} 2$

(C) $D_{2}-\mathrm{S} 2$

(D) $D_{2}-\mathrm{S} 3$

(D) $W_{2}-\mathrm{S} 3$

註 i）*印を附したものは正側繰返し昇加力法を 行つたもので、平均値の算出にあたつては 之を除外してある。

ii） ${ }_{c} F_{s}$ 中負号を附したものは、正側に於ては その荷重階の最大揱断応力度（右のカッコ

\begin{tabular}{|c|c|c|c|c|c|c|}
\hline \multirow{2}{*}{$\begin{array}{c}\text { 試: 験 体 } \\
\text { 辺長逆比 } \\
\lambda=\frac{h}{l}\end{array}$} & \multicolumn{3}{|c|}{$\begin{array}{l}\text { 悹型 開 口部を有すを壁 } \\
\xi=0.333, a=11.1 \%\end{array}$} & \multicolumn{3}{|c|}{$\begin{array}{c}\text { 釄 型開 口部を有する 壁 } \\
\xi=0.472, a=22.2 \%\end{array}$} \\
\hline & 試験体符号 & $\begin{array}{c}W G_{F} \\
\left(10^{4} \mathrm{~kg} / \mathrm{cm}^{2}\right)\end{array}$ & $\begin{array}{c}{ }_{W} F_{s} \\
\left(\mathrm{~kg} / \mathrm{cm}^{2}\right)\end{array}$ & 試験体符号 & $\begin{array}{c}W G_{F} \\
\left(10^{4} \mathrm{~kg} / \mathrm{cm}^{2}\right)\end{array}$ & $\begin{array}{c}W F_{s} \\
\left(\mathrm{~kg} / \mathrm{cm}^{2}\right)\end{array}$ \\
\hline 0.55 & $\begin{array}{l}\text { (A) } W_{2}-\mathrm{S}_{1} \\
\text { (A) } W_{2}-\mathrm{S}^{2} 2\end{array}$ & $\begin{array}{l}3.2 \\
3.7\end{array}$ & $\begin{array}{l}-3.0(3.0) \\
-5.6 \div(6.0)\end{array}$ & $\begin{array}{l}\text { (A) } \mathrm{D}_{2}-\mathrm{S} 1 \\
\text { (A) } \mathrm{D}_{2}-\mathrm{S} 2 \\
\text { (A) } \mathrm{D}_{2}-\mathrm{S} 3\end{array}$ & $\begin{array}{l}2.4 \\
2.8 \\
2.9\end{array}$ & $\begin{array}{l}-4.4(5.0) \\
5.7 \\
4.0\end{array}$ \\
\hline
\end{tabular}
内江示す）まで耐党た。

iii）剪断強度 ${ }_{c} F_{s}$ を求めたものの注かは，すべ て荷重階 $5\left(\tau= \pm 5 \mathrm{~kg} / \mathrm{cm}^{2}\right)$ て実験を止 め, 他の試験に供した。

第 $3 \cdot 3$ 表 有開口壁の剪断試験結果一覽表 


\begin{tabular}{|c|c|c|c|c|c|c|}
\hline 0.78 & $\begin{array}{l}\text { (B) } W_{2}-\mathrm{S} 1 \\
\text { (B) } W_{2}-\mathrm{S} 2 \\
\end{array}$ & $\begin{array}{l}3.0 \\
3.5 \\
\end{array}$ & $\begin{array}{r}3.8 \\
-3.5^{3}(4.0) \\
\end{array}$ & (B) $\mathrm{D}_{2}-\mathrm{S} 1$ & 1.9 & $-2.7(3.0)$ \\
\hline 1.00 & $\begin{array}{l}\text { (C) } W_{2}-\mathrm{S} 1 \\
\text { (C) } W_{2}-\mathrm{S} 2 \\
\text { (C) } W_{2}-\mathrm{S} 3 \\
\end{array}$ & $\begin{array}{l}3.1 \\
2.9 \\
3.1 \\
\end{array}$ & $\begin{array}{r}3.6 \\
3.0 \\
-3.2(4.0) \\
\end{array}$ & $\begin{array}{l}\text { (C) } \mathrm{D}_{2}-\mathrm{S} 1 \\
\text { (C) } \mathrm{D}_{2}-\mathrm{S}_{2} \\
\text { (C) } \mathrm{D}_{2}-\mathrm{S}_{3}\end{array}$ & $\begin{array}{l}1.8 \\
2.0 \\
2.3 \\
\end{array}$ & $\begin{array}{r}3.0 \\
3.9 \\
-2.8(3.0) \\
\end{array}$ \\
\hline 1.22 & $\begin{array}{l}\text { (D) } W_{2}-\mathrm{S} 1 \\
\text { (D) } W_{2}-\mathrm{S} 2 \\
\text { (D) } W_{2}-\mathrm{S} 3\end{array}$ & $\begin{array}{l}2.9 \\
3.0 \\
2.3 \\
\end{array}$ & $\begin{array}{r}3.2 \\
3.1 \\
3.0 \\
\end{array}$ & $\begin{array}{l}\text { (D) } \mathrm{D}_{2}-\mathrm{S} 1 \\
\text { (D) } \mathrm{D}_{2}-\mathrm{S} 2\end{array}$ & $\begin{array}{l}1.4 \\
1.5\end{array}$ & $\begin{array}{l}2.5 \\
2.4\end{array}$ \\
\hline 1.45 & $\begin{array}{l}\text { (E) } W_{2}-\mathrm{S} 1 \\
\text { (E) } W_{2}-\mathrm{S} 2 \\
\text { (E) } W_{2}-\mathrm{S} 3 \\
\end{array}$ & $\begin{array}{l}2.7 \\
3.1 \\
2.2\end{array}$ & $\begin{array}{l}2.4 \\
2.8 \\
2.9\end{array}$ & $\begin{array}{l}\text { (E) } \mathrm{D}_{2}-\mathrm{S} 1 \\
\text { (E) } \mathrm{D}_{2}-\mathrm{S} 2 \\
\text { (E) } \mathrm{D}_{2}-\mathrm{S} 3 \\
\end{array}$ & $\begin{array}{l}1.1 \\
1.4 \\
0.9 \\
\end{array}$ & $\begin{array}{c}1.5 \\
-1.9(2.0) \\
-1.7(2.0) \\
\end{array}$ \\
\hline
\end{tabular}

註 i） ${ }_{W} F_{s}$ は無開口队锲断面に関して算定した値である。

ii） ${ }_{W} F_{s}$ 中急号を附したものは、正側に於てはとの荷重階の最大剪断応力度（在のカッコ内に示す）まで耐 えた。

iii）開口部作製前の無開口壁飞関する ${ }_{c} G$ は第 $3 \cdot 2$ 表参照。

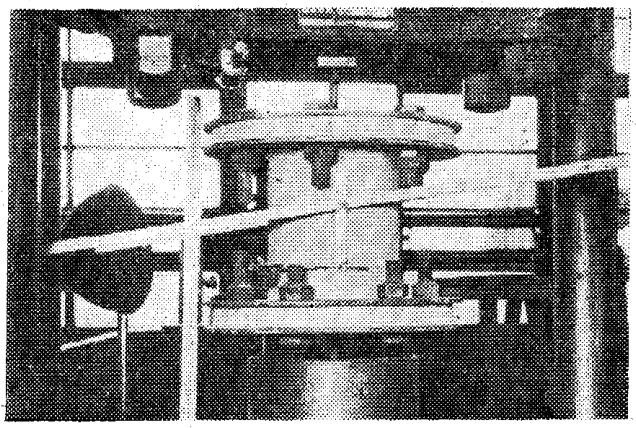

第 3.1 図 引張試験の状況

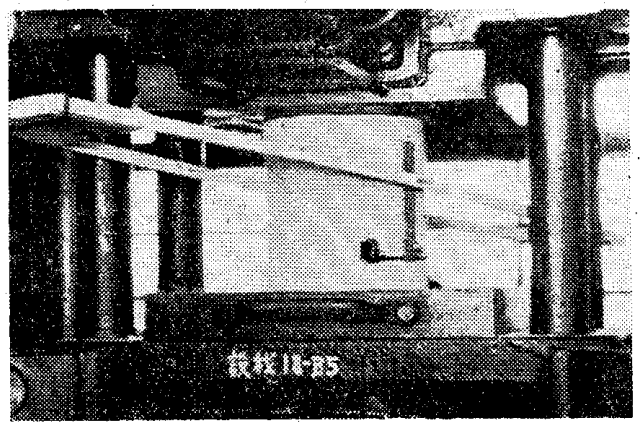

第 3.2 図 圧縮試験の状況

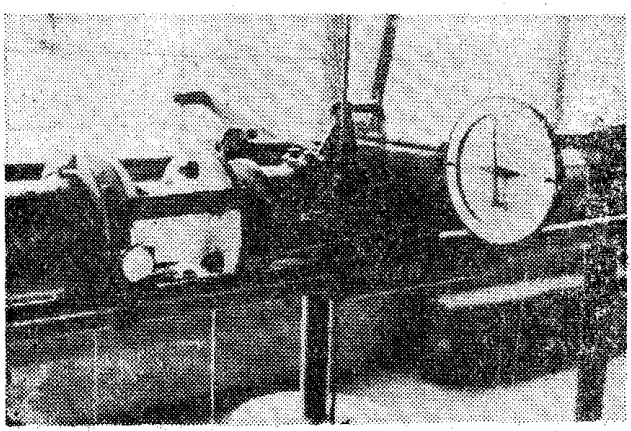

第 3 ·3 図 韶断試験の状況

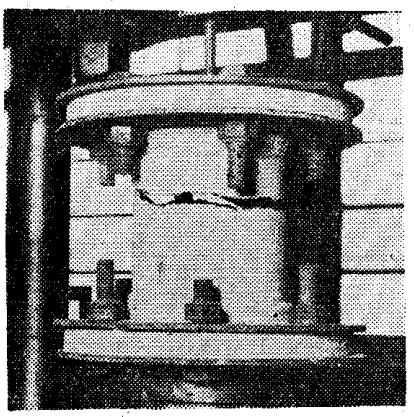

第3.4図 無開口壁の引張 破壞状況（水平破断）

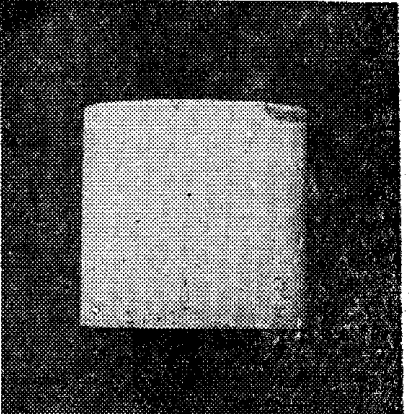

第3.5図" 無開口壁の圧縮 破壇状況（全面圧壇）

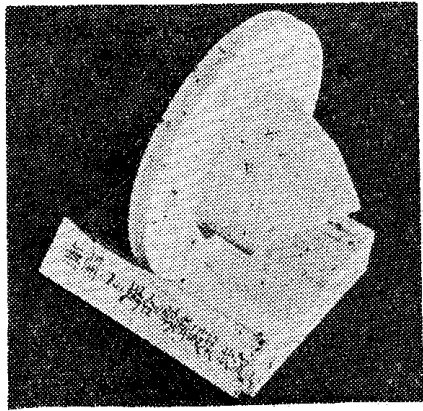

第3.6図 無開吕壁の剪断 破壤状洗（斜め破断）
$\S 3.2$ 有開口壁の横力分 布係数について

第 3.2 表に揭げた ${ }_{c} G$ 及び第 3.3 表に掲げた ${ }_{W} G_{F}$ と $\$ 1.1$ 及び $\$ 1.3$ で述べた $D_{S}$ 及び $D_{F}$ の 関係次の通りである。

$$
\begin{aligned}
D_{S} & =\frac{Q}{\delta_{S}}=\frac{Q}{h \gamma_{S}} \\
& =\frac{{ }_{c} G}{h} \cdots \cdots(3.3) \\
D_{F} & =\frac{Q}{\delta_{F}}=\frac{Q}{h \gamma_{F}} \\
& =\frac{{ }_{W} G_{F}}{h} \cdots(3.4) \\
\therefore \eta & =\frac{D_{F}}{D_{S}} \\
& =\frac{{ }_{W} G_{F}}{{ }_{c} G} \cdots(3.5)
\end{aligned}
$$

但し $\gamma_{S}$ ：無開口壁 の剪断歪度

$r_{F}$ ：有開口壁 のラーメン的変形 の部材角

第 3.11 図の実験結果 は $\eta$ と $1 / 2$ が直線的関 係沈ることを示してい る。最小二乗法によつて その実験式を求めると次 のようになる。 


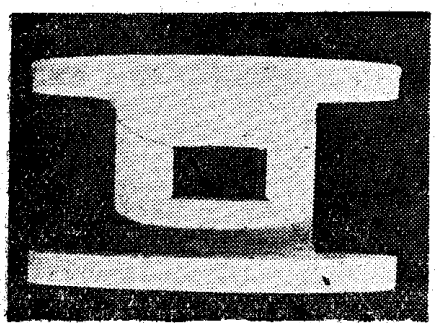

第3.7図 有開口壁(A) $W_{2}$ の破燷状況

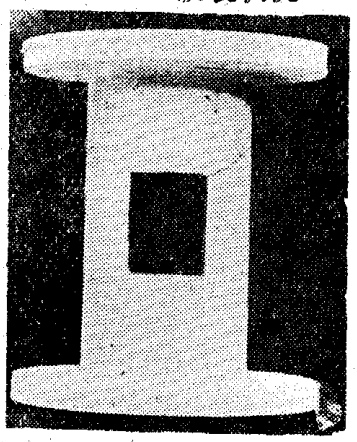

第 3.8 図 有開口壁 $(\mathrm{D}) W_{2}$ の破壞状況

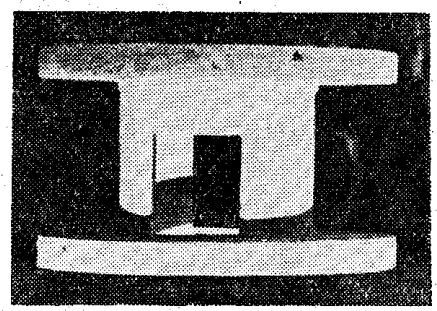

第3.9図 有開口壁 $(\mathrm{A}) D_{2}$ の破壤状況

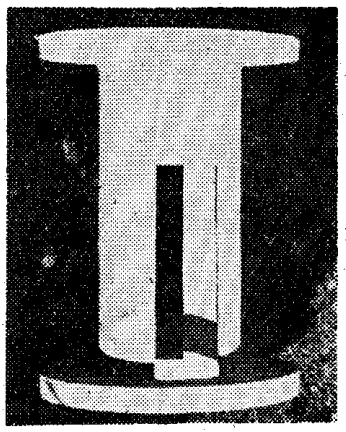

第3·10図 有開口壁 $(\mathrm{E}) D_{2}$ の破壞状況

第 3.11 図江併記した諸家の算定式值は （§1.3参照）著者の実験結果と較へてて次の相 異点が認められた。

1. $\eta$ の算定值が実験值より大で岗る。( $B$, $E, F)$

2. クがス関係なく与兄られる。 $(B, D$, $E, F)$

（但し $F$ は開口部の形状が壁の形状と 相似な場合のみこれに該当)

これらの原因として次の事が考えられる。

1. コンクリートとゴムの材料学的性質の相 異 $(B, E)$

レがクに大なる影響を与えることが坪井

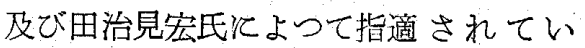
$\check{\Xi}^{29)}$ 。

コンクリート : ${ }_{c}^{\nu}=0.1 \sim 0.2$,

ゴム : $\nu \div 0.5$

2. 実験条件の相異

$B:$ 単層単張間 $E:$ 多層単張間

$F$ : 周辺が直線のま 剪断変形を起寸仮 定に立つたもので、変形が拘束されている。

3. 剪断抵抗と曲价抵抗が分離されていない（B)

4. $\eta$ 之開口形状 $(\xi, a)$ の関係注眼を置いた研究 であつて、クと入の関係を無視した。

谷口博士の旧算定式值 $(\boldsymbol{C}$ 曲線) wすで同博士が指 摘されたようと開口部の高さ $h^{\prime}$ 亿関係なくクが与 党られる不合理な点はあるが、 $h^{\prime} \div 2 h / 3$ なる有開口 壁のクの算定汇適合すると考兄られる ${ }^{16)}$ 。

$\eta$ を支配する要素は極めて多く、今回著者が行つた 実験結果から全般的結論を導くのは無理である。併し 既往の諸家の研究成果と総合し、開口偶角部の引裂重 裂発生によつて岡性低下を起す以前を対象とするク の算定式として次式提案する。

$$
\eta=1-1.25 \xi\left(1+\frac{\xi}{\lambda}\right)
$$

適用範囲 $\xi+\frac{1}{\lambda} \leqq 2.0, \quad$ 且つ $\xi \leqq 0.4$

（但し $\xi \rightarrow 0$ 亿於てスリット状となるものを除く） 上式を图表洒すと第 3.12 図となる。

第 3.8 式注次の見地から定めたものである。

1. 諸家の算定式值の傾向加考觉て、実験式 3.6 式 及び 3.7 式を直線のま $1 / \lambda \rightarrow 0$ まで外拽するこ とを認める。

2. その場合 $1 / \lambda=0$ 亿於ては武藤博士研究室算定式

屝型開口部を有する壁 $(\xi=0.472, a=22.2 \%)$

$$
\eta=-\frac{0.25}{\lambda}+0.54
$$




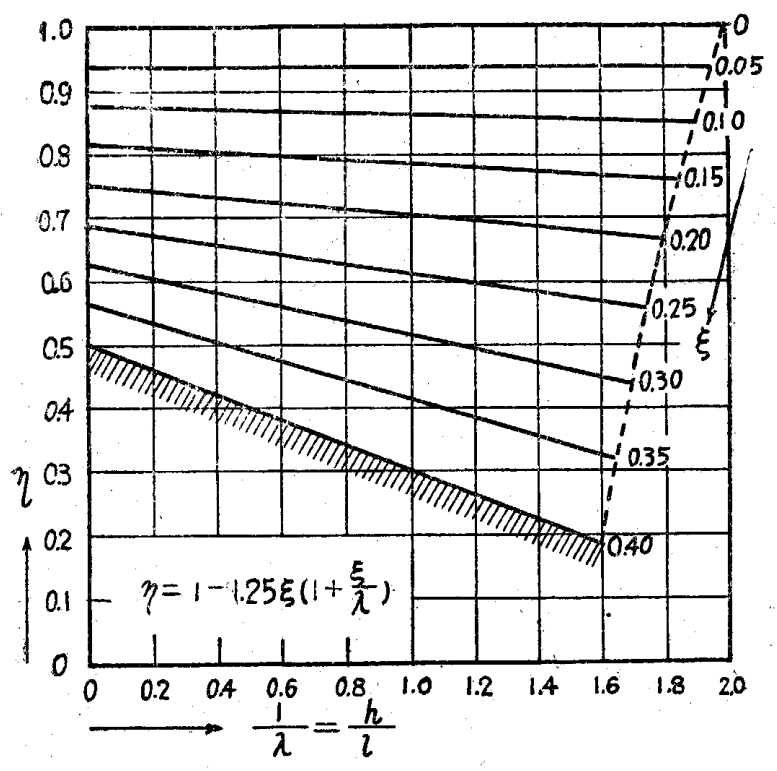

第 3.12図 著者提案の $\eta=D_{F} / D_{S} \cdot$ 以関する 算定図表

值（1.5 式）と良く符号する。註：同式値は著者 と同じ表現で $\eta=\frac{D_{F}}{D_{S}}$ を現わしている。

3. 谷口博士新図表值は $\lambda=1$ 亿於て著者の実験結果 と一番良く等合する。註：同博士新図表值は既往 の鉄筋コンクリート壁（入=1なるもの）の諸実 験結果をも考虑して定められたすのであるから、 実情に近い規準点を与えると思われる。

4. ゆ光に武藤博士研究室算定式值及び谷口博士新図 表值をそれぞれ $1 / \lambda=0$ 及び $\lambda=1$ の規準点に選 び、著者の実験結果を考慮して両者を直線で結え だ $\xi$ に関する斜線群を引いてその正切を求める そ、 $a=\xi^{2}$ に比例することを認めた。これを基に 乙算定式を簡単化するため係数を多少修正してま とめたのが 3.8 式である。

5. 適用範囲は規準点飞採つた諸家算定式の適用範囲 及び著者の実験範囲から規定したものである。開 口形状が点状に収斂する場合には $\xi=0$ に於て $\eta=1$ となるが、スリット状に収劍する場合には $\xi=0$ に於て $\eta<1$ そなる。谷口博士旧算定式は 後者に属し、その他の諸家の算定式はすべて前者 に属する。3.8 式の規準点にとつた諸家の算定式 も又すべて前者湡する。

$\xi>0.4$ なる場合は岡域のあるラーメン解法によつ てかなり正しい結果が得られるのでむしろそれによる べきであり、文 $1 / \lambda$ が大きくなれば版状と云うよりも

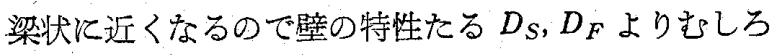
$D_{B}$ が重要な要素となり、実際問題としてもとの例は
少ないが、上記の適用範囲があれば一応充分設計に 役立つるのと思われる。

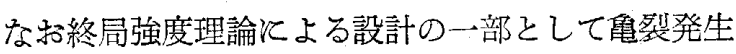
後の岡性低下を問題とする場合は、周辺架構の共同作 用及び補強筋量の多少によりクが大きく支配されるこ とが予想されるのでこれらの点関しては更に有筋壁 の実験的研究の成果に待たなければならない。

\section{$\S 3.3$ 有開口壁の破壊について}

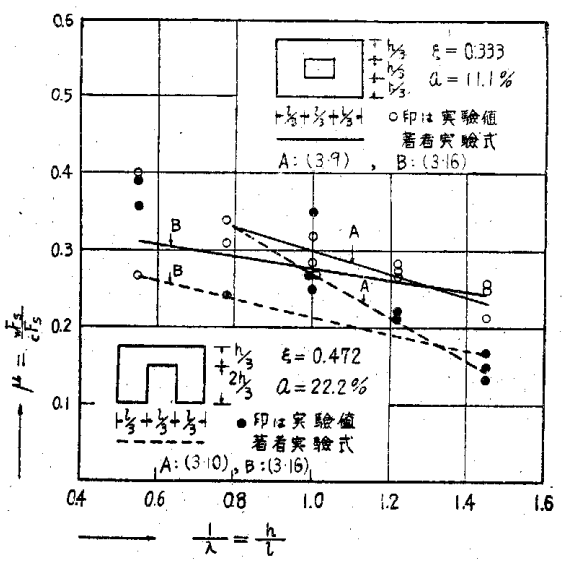

第3.13図 有開口壁の剪断強度に関する著者 の実験結果

開口隅角部に引裂茼裂を発生するとほとんどすぐ破 壊に到つた（第 3.7 図〜第 3.10 図参照）。ゆ元黾裂 応力度 ${ }_{W} F_{s} \cdot C r$ 第 3.3 表晹げた剪断强度 ${ }_{W} F_{s}$ 乙 绐とんで等しいと考えていたざければ良い。

第 $3 \cdot 13$ 図の実験結果は $1 / \lambda<1$ なる場合実験值がか なり散布しているが、一応 あるものとして最小二乗法沉つてその実験式を求め ると次のようになる。

空型開口部を有する壁 $(\xi=0.333, a=11.1 \%)$

$$
\mu=-\frac{0.15}{\lambda}+0.45
$$

扉型開口部を有する壁 $(\xi=0.472, a=22.2 \%)$

$$
\mu=-\frac{0.28}{\lambda}+0.55
$$

上記の各式は $A$ 線として第3.13 図中記入されて いるが、これは $1 / \lambda$ が小となると両者の ${ }_{W} F_{s}$ が変ら なくなることを示している。これは坪井及び田治見宏 氏が示した開口偶角部の附加引裂応力 $T$ K関する略 算式（第 3.14 図参照）

$$
T \doteqdot \frac{D t}{2} \tau
$$

但し $D$ : 開口部の対角線の長さ

$t$ : 壁の厚さ

$\tau ：$ 無開口断面に関する剪断応力度 
の特性と符合する ${ }^{29)}$ 。(1/ス が小となれば両者のDの差 も小となる。)

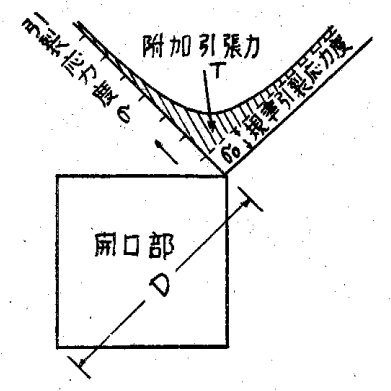

第3.14 図 開口偶刍部の引裂龜裂算定に関 する諸記号

これから

$$
\begin{aligned}
& \sigma_{0}+\frac{T}{\alpha l t}={ }_{c} F_{s} \ldots \ldots \ldots \ldots \ldots . . \\
& \left\{\frac{1}{1-m}+\frac{D t}{2 \alpha l t}\right\}{ }_{W} F_{s}={ }_{c} F_{s}
\end{aligned}
$$

$\therefore \mu=\frac{{ }_{W} F_{s}}{{ }_{c} F_{s}}=\frac{1}{\frac{1}{1-m}+\frac{1}{2 \alpha} \cdot \frac{D}{l}}$.

但し $m$ : 開口長さ $l^{\prime}$ と壁の長さ $l$ の比 $m=l^{\prime} / l$ $\alpha$ : 附加引裂応力 $T$ の分散効果をあらわす 係数
実験結果より

$$
\frac{1}{2 \alpha}=4.5
$$

と置くと次のような算定式を得る。

$$
\mu=\frac{{ }_{W} F_{s}}{{ }_{c} F_{s}}=\frac{1}{\frac{1}{1-m}+4.5 \frac{D}{l}}
$$

上式の結果を $B$ 線として第 3.13 図に記入してめる が、これは大体安全側の結果を示している。

武藤博士及び黒正清治氏が行つた架構付き有開口壁 の害験 ${ }^{5)}$ 亿関する重裂発見剪断応力度 $W F_{s} \cdot \mathrm{Cr}$ と $3 \cdot 16$ 式の結果を比較すると、無筫の場合ほ良く符号し、偶 角部反斜補強筋を有する有筋の場合は $2 \cdot 16$ 式より大 きな結果を示している（第 3.4 表参照）。これら架構 付き有開口壁の結果及び著者が行つた有開口単独壁の 実験結果から一応次のととが結論される。

1. 周辺架構は終局強度を高めるが、開口隅角部に於 ける引裂奄裂の発生を防止する役目はない。

2. 隅角部補強筋は終局強度を高めるととるに、開口 隅角部於ける引裂龟裂の発生防止にも有效であ る。

3. 無穊壁の場合、単独壁にあつては ${ }_{W} F_{s \cdot C r} \doteqdot W F_{S}$ を意味し、架構付き壁にあつては ${ }_{W} F_{s} \cdot C r$ 快岡性 低下の起点を表わすことになり、これらはそれぞ

\begin{tabular}{|c|c|c|c|c|c|c|c|}
\hline \multicolumn{5}{|c|}{ 武藤博士研究室実験 結 果 } & \multicolumn{3}{|c|}{3.16 式の算定結果 } \\
\hline 試験体符号. & $\begin{array}{c}{ }_{c} F_{c} \\
\left(\mathrm{~kg} / \mathrm{cm}^{2}\right)\end{array}$ & $\begin{array}{c}{ }_{c} F_{s} \text { (推定) } \\
\left(\mathrm{kg} / \mathrm{cm}^{2}\right)\end{array}$ & $\begin{array}{c}W F_{s . C r} \\
\left(\mathrm{~kg} / \mathrm{cm}^{2}\right)\end{array}$ & $\mu=\frac{{ }_{W} F_{s \cdot C r}}{{ }_{c} F_{s}}$ & $\frac{l^{\prime}}{l}=m$ & $\frac{D}{l}$ & $\mu$ \\
\hline $\mathrm{PCO}-\mathrm{B}$ (無筋) & 200 & 20 & $\begin{array}{l}4.2 \text { (2 層) } \\
5.5 \text { (1 層) }\end{array}$ & $\begin{array}{l}0.21 \text { ( } 2 \text { 層 }) \\
0.28 \text { ( } 1 \text { 層 })\end{array}$ & $\frac{12 \mathrm{~cm}}{30 \mathrm{~cm}}=0.4$ & $\frac{14.8 \mathrm{~cm}}{30 \mathrm{~cm}}=0.5$ & 0.26 \\
\hline $\mathrm{RCO}-\mathrm{B}$ (有筋) & 260 & 26 & $\begin{array}{l}12.5 \text { (2 層) } \\
14.5 \text { ( } 1 \text { 層 })\end{array}$ & $\begin{array}{l}0.48 \text { (2 層) } \\
0.56 \text { ( } 1 \text { 層 })\end{array}$ & $\frac{10 \mathrm{~cm}}{30 \mathrm{~cm}}=0.33$ & $\frac{12 \mathrm{~cm}}{30 \mathrm{~cm}}=0.4$ & 0.31 \\
\hline 辣 ${ }_{W} \mathrm{~F}_{s \cdot C_{r}}$ & ま寒験値を & 開口断面 & 算して揭載 & & & & \\
\hline
\end{tabular}

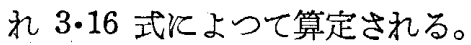

第 3.4 表 開口隅角部の重裂発見剪断応力度 $W_{s} F_{s} \cdot C r$ 亿関する武藤博士研究室実験値 ${ }^{5)}$ 々 著者提案の算定式值 $(3.16$ 式) の比較

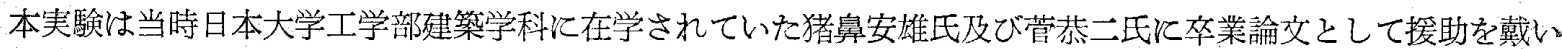
たもので、ここに謝意を表します。本研究は文部省科学研究費によつた。 


\section{参考 文 献}

略称 建雑 : 建築雑誌

建論：日本建築学会論交炛（旧大会論文集を 含を)

建報：日本建築学会研究報告、

建報（大）：同大会号

備考 i *印を付したるのは有開口壁に関係むる 80

ii 同一内容が重復して発表されているもの は、その中で最新のものを揭載した。

1. 鉄筋コンクリート壁の剪断抵抗に関する静的実 験

a. 鉄筋コンクリート（モルタルを含む）による直 接实験

1）内藤多仲、福島惟男：「実験に依る壁体及び架 構の横力分布係数について」陸軍建築䭛話会、 大 15

2）田辺平学：「鉄筋コンクリート版の応剪抵抗に 関する研究」神戸高等工業学校紀要、第 2 巻、 昭 $5 \cdot 6$

3) 田辺平学、勝田千利、東東造：「耐震壁飞関す る研究 第 1 報〜第 4 報」建論 昭 8 ，昭 9 ， 建雑 昭 10.3 、建論 昭 10

4) 東大武藤研㶢室 小倉弘一郎、黑正清治、その 他：「耐震壁の研究 その $2,7,10,16,18$ （実験的考察 1 5) 鉄筋コンクリート一層耐震 壁についての塞験的研究」建報 $6 、 8 、 12(大)$ 13,16 各号、昭 25.5 , 昭 25.10 , 昭 26.6 , 昭 26.8 , 昭 26.12

5)*武藤清、黒正清治：「鉄筋コンクリート二層耐 震壁についての害験的研究」，建論 47 号、昭 28.9

6)*鶴田明、佐野弘、松开源吾：「耐震壁の鉄筋コ ンクリート模型実験報告」建報 21 号、昭 28.3

7)*松并源吾 : 「剪力を受ける架構付き壁体の鉄筋 コンクリート模型実験」建報 21 号、昭 28.3

8）坪井善勝、富并政英：「鉄筋コンクリート版の 剪断抵抗化就いて 第 1 報」建報 4 号、昭 24 . 11

9）块井善勝、富井政英：「鉄筋コンクリート無開 口単独壁の剪断担抗関する研究」建諭 47 号、 昭 28.9

10)* 玶井善勝、田治見宏、星野一郎：「壁式構造に 関する一問題」建報 9 号、昭 25.11

11)*中う恭次、鈴木正治、大崎順彦：「壁式アパー 卜模型耐力詰験」各種建築物の耐震度に関する 研究報告 1 号、耐震試験委員会、昭 26.3

12)*小野薰、任治泰次：「模型による耐震試験」各 種建築物の耐震度海関する研究報告 1 号、耐震 訊験委員会、昭 26.3

b。弾性体による間接実験
13)* 棚橋諒：「壁体の開孔飞依る風度効率の減少」 建論、昭 9

14)* 坂静雄：「耐震壁の横力負担に対する開口の影 響」日本学術與会第 14 小委員会報告 2 号、昭 17.8

15)* 坂静雄 :「矩形耐震壁の横力負担々開口の影響」 建論 30 号、昭 18.9

16)* 谷口忠：「耐震壁飞関する研究（その1）」建 論 41 号, 昭 25.8

17)*東大武藤研究室 大沢滘、その他：「耐震壁の 研究 その 26、27 二層開口耐震壁のゴム模型 実験（矩形、正方形）その 28 三層開口耐震壁 のゴム模型実験（正方形）」建報21，24（大）， 25 各号, 昭 28.3 , 昭 28.10 , 昭 29.3

18)* 二見秀雄、藤本盛久：「壁体応力の光弾性実験 (一層)」，建報（大） 12 号、昭 26.6

19)* 二見秀雄、藤本盛久：「壁体応力の光弾性実験 (二層)」 建論 47 号、昭 28.9

20)*大崎順彦、松开源吾、高田鎌三郎：「壁式アパ 一トの光弾性実験」建報 10 号、昭 26.4

21）松井源吾：「剪力を 5 ける架構付き開口壁の光 弾性実験報告」建報（大） 24 号、昭 28.10

22 * *宮崎俊二：「光弾性によるラーメン部材及び節 点の応力解析」名古屋工業大学学報 第 3 号、 昭 26.12

2. その他の関係䚺献

a. 実験的研究

23）武藤清、黑正清治：「鉄筋コンクリート剪断破 壞実験法の提案」建報 20 号、昭 27.10

24) E. Mörsh : "Schub und Scherfestigkeit des Betons", Schweizerische Bauzeitung, Bd. XLIV, S. 307-310, 1904.

25) Bach und Graf: "Versuche über die Widerstandfahigkeit von Beton und Eisenbeton gegen Verdrehung', Veroffentlichungen des deutshen Aussuchusses für Eisenbeton, Heft 16, 1912.

26) B. Bresler and E. Wollak : "Shear Strength of Concrete," A Paper presented at the Anual Convention of the Structural Engineers Association of California at Riverside, California. Oct. 1952.

b. 理論的研究

27)* 佳野利器、谷口忠：「面震構造汎論」岩波全書 No.30、昭 9.9

28 * *武藤清 :「構造設諳法」建築学大系 14 、彰国社、 昭 29.9

$29) *$ 坪并善勝、田治見宏：「開口を有する壁体につ いて」建報 6 号、昭 25.5

30)，坪开善勝、富并政英：「直交異方性弹性版理論 による鉄筋コンクリート壁の鼠裂発生後に於け る剪断抵抗の解析」建論 48 号、昭 29.3 